\title{
Indonesian Comparative Advantage Entering the ASEAN Economic Community
}

\author{
Riandi, Yulius Pratomo \\ Department of Economics, Satya Wacana Christian University, Indonesia \\ E-mail (corresponding author): yulius.pratomo@staff.uksw.edu
}

Received: September 3, 2016; Accepted: January 12, 2016; Published: March 2, 2017

Permalink/DOI: http://dx.doi.org/10.17977/um002v9i12017p086

\begin{abstract}
The purpose of this study is to examine the comparative advantage of Indonesian commodities in order to enter the ASEAN Economic Community (AEC). This study uses the export data during the period of 2003-2013 among five ASEAN countries participating in the AEC, including Indonesia, Malaysia, The Philippines, Singapore, and Thailand. All data obtained from the UN Comtrade database following the Harmonized System (HS) at the two-digit classification level. This study applies dynamic revealed comparative advantage (DRCA) index developed by Edwards and Schoer (2001) which is the development of revealed comparative advantage (RCA) index by Balassa (1965). The results show that Indonesia is ready to enter the AEC. From this research, there are several Indonesian main commodities which have comparative advantage in ASEAN, including fish, crustaceans, molluscs, aquatic invertebrates ones (HS-03), edible fruit, nuts, peel of citrus fruit, melons (HS-08), oil seed, oleagic fruits, grain, seed, fruit, etc, nes (HS12), lac, gums, resins, vegetable saps and extracts nes (HS-13), rubber and articles thereof (HS-40), paper \& paperboard, articles of pulp, paper and board (HS-48), special woven or tufted fabric, lace, tapestry etc (HS-58), articles apparel, accessories, not knit or crochet (HS-62), and vehicles other than railway, tramway (HS-87). Those commodities are in line with Indonesian government export's strategy direction which mainly focuses on several sectors, including fishery, vegetable products, rubber, wood and wood products, textiles, and transportation. Therefore, Indonesian government should focus to improve those commodities in AEC.
\end{abstract}

Keywords: Indonesian Comparative Advantage, Main Export Commodities, Export Strategy Direction, ASEAN Economic Community

JEL Classification: F11, F43

\section{INTRODUCTION}

ASEAN Economic Community (AEC) is a form of economic cooperation of the ASEAN nations. This cooperation, as has been explained (Bustami, 2008), has set the Southeast Asian region into a single market where the flow of goods, services, investment, skilled labor, and capital flows are freely moved among the countries. Currently, there are six ASEAN members which have joined the AEC, such as Brunei Darussalam, the Philippines, Indonesia, Malaysia, Thailand, and Singapore. Four other ASEAN countries, including Cambodia, Laos, Myanmar, and Vietnam will join later in period 2018-2020. 
There is a lot of discussion in Indonesia about the readiness of the country to enter. Those are pessimistic, but the others sound optimistic. The pessimistic side argues that the strategy and preparation undertaken by Indonesia is still considered weak because of corruption (Sholeh, 2013). Meanwhile, the opponent reveals that Indonesia does not need to be pessimistic because the country has 12 sectors which are predictive to be competitive in AEC. Those sectors consist of eight sectors of trading in goods, such as agriculture, fisheries, rubber industry, wood industry, textile and apparel industries, automotive, electronics, and information technology and communications, and four sectors in services, including health, tourism, air transportation, logistics, and e-commerce (Gayati, 2014).

In the academic field, there has also been a discussion about the readiness of Indonesia in the AEC. However, the discussions are still limited to a particular commodity and do not discuss the link of those commodities' competitiveness with the Indonesian government's export strategy direction. The results of Muslim's study (2006), for example, show that Indonesia, despite getting competition from India and the Philippines, is able to be competitive in coconut based agro-products and can specialize its exports to some destinations, such as China, Malaysia, Russia, and Singapore. Other findings from Ragimun (2012a) show that Indonesia is suitable as an exporter of footwear, especially exports to China. Furthermore, Maulidy \& Widyasanti (2011) show that Indonesia has export products from the manufacturing sector, such as chemicals and chemical products; iron and steel; non-ferrous metals; metallic items; equipment and general industrial machinery; and other transport equipment. Kalaba (2012), on another occasion, reveals that all Indonesian cocoa products, ranging from grains, pasta, fats, until the cocoa powder, have competitiveness in the international market. Kalaba (2012) findings are supported by Rifin (2013) who finds that Indonesian cocoa production has competitiveness when compared with production of cocoa from Côte d'Ivoire, Ghana, and Nigeria, although the competitiveness level of those countries are higher.

This article, therefore, considers the importance of analyzing the competitiveness of commodities produced by Indonesia's economy in order to help to determine the commodities that have comparative advantage in international trade. Hence, this study aims to examine Indonesia's commodities which are able to compete within the scope of international trade, especially in ASEAN region. Hopefully, by knowing the main commodities, the Government of Indonesia can focus on developing those commodities in AEC. This study can also be used as an instrument to determine the readiness of Indonesia to face the AEC. This paper, furthermore, is about to answer the following questions. First, what Indonesian commodities that have a comparative advantage? Second, are these commodities in line with the policy direction of the Indonesian government for the development of leading sectors of export? Third, does Indonesia ready to enter the AEC?

\section{LITERATURE REVIEW}

\section{Theory of Comparative Advantage and Global Competitiveness Index}

Theoretically, commodities' competitiveness in the global or regional level can be determined by applying the theory of comparative advantage by David 
Ricardo at the empirical level. A commodity is claimed to be competitive at the global or regional level if the commodity has a comparative advantage. To be kept in mind, the theory of comparative advantage reiterates that each country can do international trade because each country has comparative advantages (Bouare, 2009), or specifically have comparative cost advantages in producing goods or commodities (Aldrich, 2004).

Recently, studies on the competitiveness of the commodities in the global or regional context are not only be based on the comparative advantage of the commodities but also be based on the Global Competitiveness Index (GCI) [see Ragimun (2012b) and Hermana (2004)]. GCI is published annually by the World Economic Forum (WEF). WEF itself is an independent international institution which has the goal of improving economic growth and social development of countries in the world. GCI compares the productivity and efficiency of the countries. In addition, GCI also shows the comparative advantages of countries in the world. GCI explores in depth about the efficiency of the various sectors of the countries' economy and the contribution of the sectors to the productivity of the countries. This is useful because GCI can identify the strengths and weaknesses of the nations' economy. Several indicators measured in the GCI are macroeconomic stability, institutions, infrastructure, health and primary education, the level of higher education and training, market efficiency (in terms of product, labor, and capital), technological readiness (economy's ability to adapt to technology existing), business sophistication, and innovation.

\section{Results of the Previous Research}

Many researchers from various countries have done research on the comparative advantages. First, Balassa \& Noland (1989) examines changes in comparative advantage of Japan and the United States. During the period 19671983, they find that the pattern of Japan's specialization has changed dramatically. Japan shifts from specialization in intensive goods with unskilled labor into human capital intensive products. Nonetheless, Japan experiences the loss of comparative advantage in natural resources intensive products. For the United States, Balassa \& Noland (1989) contend that the country specializes in physical capital-intensive and capital-intensive goods while increasing the labor-intensive products in natural resources. To sum up, Balassa \& Noland (1989) argue that Japan and the United States increase their comparative advantage in high technology.

Next, Widgrén (2005) examines the comparative advantages of selected countries in Asia, America, and Europe between 1996 and 2002. The study is conducted by calculating the Balassa index using industry data on HS 4-digit level. The main part of the analysis concentrates on the intensity factor of the countries' comparative advantage. Widgrén (2005) shows that there are several convergences in terms of content factor of comparative advantage among Asian countries, the new member states, and the European Union 15. According to Widgrén (2005), the comparative advantage of the European Union (EU) has recently been moving towards intensive use in both human and physical capital.

Furthermore, Serin \& Civan (2008) examines the comparative advantage of Turkish commodities, including tomatoes, olive oil, and fruit juice. They ask how those commodities can progress in the EU market from 1995 to 2005. Serin 
\& Civan (2008) do the research because the EU is the largest market for Turkish exports, such as processed fruits and vegetable products. Serin \& Civan (2008) use the RCA and CEP index. Their results show that Turkey is very superior in fruit juice and olive oil, but not with tomatoes.

Then, Suntharalingam et al. (2011) examine the ability to be sold of Malaysian fruits in the competitive global agricultural markets. According to Suntharalingam et al. (2011), free trade has increased tropical fruit trade which leads to a wider global competition. Therefore, Suntharalingam et al. (2011) do some research to see the position of Malaysian fruit products in competition with other exporters. Suntharalingam et al. (2011) use RCA and CEP index in their studies. They find that Malaysian most superior products are watermelon and papaya. Malaysia are advised by Suntharalingam et al. (2011) to focus on developing of watermelon and papaya to maintain their competitiveness.

Another study is in Swaziland. Karambakuwa \& Mzumara (2013) investigate the comparative advantages of Swaziland. They investigate whether Swaziland has comparative advantages in products which are exported to the Common Market for Eastern and Southern Africa (COMESA), Southern African Development Community (SADC), the Southern Africa Customs Union (SACU) and the rest of the world. Karambakuwa \& Mzumara (2013) indicate that Swaziland has RCA $\geq 1$ on 449 product lines. According to them, chem wood pulp, sulfite, coniferous unbleached have the highest RCA. Other main products of Swaziland are manufacturing and agricultural products. Karambakuwa \& Mzumara (2013) argue that Swaziland can increase the variety of products which have comparative advantages through attracting foreign direct investment via transnational companies and the exploration of new resources.

Next, Ishchukova \& Smutka (2013) study the comparative advantages of Russia in agricultural products and foodstuffs over the period 1998-2010. They use the Balassa index, the Vollrath index, and the Lafay index. The Balassa index is used to identify the groups of products which have comparative advantages. The Vollrath Index is used to show the number of products that already have a competitive advantage, and whether they grow during the period. Due to geographical location and good trade relations with Commonwealth of Independent States (CIS) and Asian countries, The Lafay index is used in regional analysis to show Russian comparative advantages in relation with those countries. From their study, Ishchukova \& Smutka (2013) show that primary products of Russia (e.g. wheat, cow's milk, sunflower seeds, and others) have comparative advantages compared to the EU and Asian countries. In connection with the whole world, Ishchukova \& Smutka (2013) indicate that the by-products (e.g. bran) have comparative advantages in 1998-2001, while the primary products have comparative advantages in the year 2002-2010.

In sum, the results from previous studies in various countries have shown that understanding of the comparative advantage of a commodity in a country is useful. Conclusions of any research on the comparative advantage have been carrying advice regarding commodities to be maintained or developed further by any countries. Therefore, Indonesia needs to prepare any commodities that have comparative advantages in order to compete with other ASEAN countries in AEC. 


\section{METHOD}

Data

The data used in this study are data of export (in value) during the period of 2003-2013 from five ASEAN countries that participated in AEC, including Indonesia, Malaysia, Philippines, Singapore, and Thailand. In this study, the data are used only from five countries due to export data of Brunei Darussalam are not complete and therefore cannot be used in this study. All data are obtained from UN Comtrade database following the Harmonized System (HS) at the two-digit level classification.

\section{Analytical Tools}

This study measures the comparative advantages of Indonesian commodities by using two methods of measurement, i.e. static and dynamic. Static measurement method uses the Revealed Comparative Advantage (RCA) index, whereas the dynamic method uses Dynamic Revealed Comparative Advantage (DRCA) index. Static measurement is useful to look at the condition of the commodity at a certain point in time, while the dynamic measurement is useful to see the development of a commodity for a certain period, so the dynamic measurement can view commodities with potential to be developed in the future.

The observation is divided into two periods, before and after the global financial crisis in 2008. This is due to the global financial crisis have a significant impact on exports (Firdaus, 2009), so that the period of observation need to be separated.

\section{Revealed Comparative Advantage (RCA)}

Revealed comparative advantage or commonly called RCA is a method to find products that have a comparative advantage. RCA is an index widely used, formulated by Balassa (1965). The index is defined as:

$$
\operatorname{RCA}_{\text {Balassa }}=\left(\begin{array}{l}
\frac{X_{\mathrm{j}, \mathrm{i}}}{\mathrm{X}_{\mathrm{t}, \mathrm{i}}} / \\
/ \frac{\mathrm{X}_{\mathrm{j}, \mathrm{n}}}{\mathrm{X}_{\mathrm{t}, \mathrm{n}}}
\end{array}\right)
$$

$\mathrm{X}_{\mathrm{j}, \mathrm{i}}$ is export of the $\mathrm{j}$-th product in country $\mathrm{i}$. $\mathrm{X}_{\mathrm{t}, \mathrm{i}}$ is total exports in country j. $X_{j, n}$ is export of the $j$-th product in the reference area. $X_{t, n}$ is total exports in the reference area. If the RCA index is greater than $1(\mathrm{RCA}>1)$, then it indicates that a product has comparative advantage, and vice-versa.

This study uses the Balassa's RCA index to examine Indonesia's comparative advantage by using two different reference areas, including ASEAN5, and the world. To find Indonesia's comparative advantage within the ASEAN-5 (AEC), this study uses this formula:

$$
\operatorname{RCAAEC~}_{A}=\left(\frac{X_{j, \text { Inda }}}{X_{t, \text { Inda }}} / \frac{X_{j, A S N}}{X_{t, A S N}}\right)
$$

$\mathrm{X}_{\mathrm{j} \text {,Inda }}$ is export of the $\mathrm{j}$-th product in Indonesia to ASEAN-5. $\mathrm{X}_{\mathrm{t} \text {,Inda }}$ is total exports in Indonesia to ASEAN-5. $X_{j, A S N}$ is export of the $j$-th product in ASEAN-5. $X_{t, A S N}$ is total exports in ASEAN-5. 
Further, this study also examine Indonesian comparative advantage in the global market. The formula to find Indonesian comparative advantage at this level is:

$$
\text { RCAworld }=\left(\frac{X_{j . I n d w}}{X_{t . I n d w}} / \frac{X_{j . W o r l d}}{X_{t . W o r l d}}\right)
$$

$\mathrm{X}_{\mathrm{j} \text {,Indw }}$ is export of the $\mathrm{j}$-th product in Indonesia to the rest of the world (minus ASEAN-6); $X_{t, \text { Indw }}$ is total exports in Indonesia to the rest of the world (minus ASEAN-6); $X_{j}$,World is export of the $j$-th product in the world; and $X_{t, \text { World }}$ is total exports in the world. Currently as explained, AEC consists of six countries in ASEAN. Therefore, ASEAN-6 is used to find Indonesian comparative advantage in the global market.

\section{Dynamic Revealed Comparative Advantage (DRCA)}

After getting the value of RCA (static), the next step is calculating the dynamic RCA index. Dynamic RCA (DRCA) is the modified version of the RCA. This appears as RCA index considered less suitable for the analysis of changes in competitiveness over time (Valentine \& krasnik, 2000). Later, Edwards and Schoer (2001) has constructed DRCA $(\triangle R C A j / R C A j)$ index as follows:

$$
\frac{\Delta R C A j}{R C A j}=\frac{\Delta\left(X_{j, i} / \sum_{j} X_{j, i}\right)}{X_{j, i} / \sum_{j} X_{j, i}}-\frac{\Delta\left(X_{j, w} / \sum_{j} X_{j, w}\right)}{X_{j, w} / \sum_{j} X_{j, w}}
$$

The first part reflects the growth of the share of total trade of commodity $j$ in country $i$. The second part reflects the growth of the share of commodity $j$ in the world trade. Edwards and Schoer (2001) explain that DRCA > 0 indicates superiority, while DRCA $<0$ means the opposite. The greater the positive value, the greater the advantage of a commodity and vice-versa. Further, there are two dynamic models used in this study. The data used are the RCA indices which have previously undertaken within two different reference areas, i.e. AEC and in the world.

\section{RCA and DRCA Matrix}

After obtaining $\mathrm{RCA}_{\mathrm{AEC}}$ and RCAwORLD indices, the results are constructed into the form of a matrix. This is to view the competitiveness of each commodity. The RCA matrix is as the following:

Table 1. RCA Matrix

\begin{tabular}{ccc}
\hline & RCAwORLD $>\mathbf{0}$ & RCAwORLD $\leq \mathbf{0}$ \\
\hline $\boldsymbol{R C A}_{\text {AEC }}>\mathbf{0}$ & I & II \\
\hline $\boldsymbol{R C A}_{A E C} \leq \mathbf{0}$ & III & IV \\
\hline
\end{tabular}

$\mathrm{RCA}_{\mathrm{AEC}}$ and RCAwORLD $>0$ indicate Indonesia's competitive products in AEC and in the global market. RCAAEC $>0$ and RCAworLD $\leq 0$ indicate Indonesia's competitive products in AEC market, but still unable to compete in the global market. $\mathrm{RCA}_{\mathrm{AEC}} \leq 0$ and $\mathrm{RCA}_{\text {WORLD }}>0$ indicate Indonesia's competitive products in the global market, but less superior in AEC market. $\mathrm{RCA}_{\mathrm{AEC}}$ and RCA $\mathrm{WORLD}_{\mathrm{W}} \leq 0$ indicate Indonesia's commodities do not have competitiveness in AEC and global market. 
Further, after obtaining DRCA $\mathrm{AEC}_{\mathrm{AEC}}$ and DRCAwORLD indices, the results are constructed into the form of a matrix. This is to view the potential of each commodity. The DRCA matrix is as the following:

Table 2. DRCA Matrix

\begin{tabular}{ccc}
\hline & DRCAWORLD $>$ 0 & DRCAwORLD $\leq \mathbf{0}$ \\
\hline DRCAAEC $^{>0}$ & I & II \\
\hline DRCAAEC $\leq \mathbf{0}$ & III & IV \\
\hline
\end{tabular}

DRCA $_{A E C}$ and DRCAwORLD $>0$ indicate Indonesia's commodities which have positive trend in AEC and in the global market. DRCA $_{\mathrm{AEC}}>0$ and DRCAwORLD $\leq 0$ indicate Indonesia's commodities which have positive trend in the AEC market, but have negative trend in the global market. $\mathrm{DRCA}_{\mathrm{AEC}} \leq 0$ and DRCAworLd $>0$ indicate Indonesia's commodities which have positive trend in the global market, but have negative trend in AEC market. DRCA $A_{\mathrm{AEC}}$ and DRCAwORLD $\leq 0$ indicate Indonesia's commodities which have negative trend in $\mathrm{AEC}$ and in the global market.

\section{RESULT AND DISCUSSION}

From 97 commodities, there are 47 commodities where those data are incomplete. Therefore, those commodities cannot be analyzed. For other 50 commodities, the data are complete. Therefore, those can be processed for further analysis. Here are the results of analysis and discussion.

\section{Indonesia's Main Commodities}

Calculations of $\mathrm{RCA}_{\mathrm{AEC}}$ and RCAworLD indices are divided into two periods, i.e. before and after the global financial crisis in 2008. After calculating RCA $_{\mathrm{AEC}}$ and RCAwORLD indices, the commodities are grouped into a matrix form. Here are the results:

Table 3. RCA Matrix, Period 2003-2008

\begin{tabular}{|c|c|c|c|c|c|}
\hline & \multicolumn{2}{|c|}{ RCA $_{\text {WORLD }}>0$} & \multicolumn{3}{|c|}{$\mathbf{R C A}_{\text {WORLD }} \leq \mathbf{0}$} \\
\hline \multirow{6}{*}{$\begin{array}{c}\mathbf{R C A}_{\mathrm{AEC}} \\
\quad>\mathbf{0}\end{array}$} & HS-03 & HS-48 & HS-04 & HS-30 & HS-72 \\
\hline & HS-13 & HS-61 & HS-08 & HS-56 & HS-73 \\
\hline & HS-27 & HS-62 & HS-12 & HS-63 & HS-76 \\
\hline & HS-34 & HS-64 & HS-19 & HS-68 & HS-83 \\
\hline & HS-40 & HS-74 & HS-25 & HS-70 & HS-87 \\
\hline & HS-44 & HS-94 & HS-28 & HS-71 & HS-96 \\
\hline \multirow{7}{*}{$\begin{array}{c}\mathbf{R C A}_{\mathrm{AEC}} \\
\leq \mathbf{0}\end{array}$} & HS-16 & & HS-17 & HS-35 & HS-84 \\
\hline & & & HS-21 & HS-38 & HS-85 \\
\hline & & & HS-22 & HS-39 & HS-88 \\
\hline & & & HS-23 & HS-42 & HS-90 \\
\hline & & & HS-29 & HS-49 & HS-95 \\
\hline & & & HS-32 & HS-58 & \\
\hline & & & HS-33 & HS-82 & \\
\hline
\end{tabular}

Source: Secondary data from UN Comtrade, processed. 
Table 3. reveals that in period 2003-2008 there are 12 (24\%) Indonesian commodities which have RCA index, RCA $\mathrm{AEC}_{\mathrm{A}}$ and RCAworLD, greater than 1. It means that those commodities have competitiveness not only in the AEC market but also in the global market. Further, in period 2003-2008 there are 18 (36\%) Indonesian commodities which have competitiveness in AEC market but not in the global market. Next, in period 2003-2008 there is one of Indonesian commodities which has competitiveness in the global market but not in AEC market. Unfortunately, in periode 2003-2008 there are 19 (38\%) Indonesian commodities which have no competitiveness either in AEC or global market. Overall, in period 2003-2008 there are 30 (60\%) Indonesian commodities which have competitiveness in AEC market. It means that before the global financial crisis Indonesia tends to be ready to enter the AEC.

Table 4. RCA Matrix, Period 2009-2013

\begin{tabular}{|c|c|c|c|c|c|}
\hline \multirow{3}{*}{$\underset{\mathbf{0}}{\mathrm{RCA}_{\mathrm{AEC}}>}$} & \multicolumn{2}{|c|}{ RCA $_{\text {WORLD }}>0$} & \multicolumn{3}{|c|}{ RCA $_{\text {WORLd }} \leq 0$} \\
\hline & HS-03 & HS-48 & HS-04 & HS-21 & HS-83 \\
\hline & HS-27 & HS-62 & HS-08 & HS-30 & HS-87 \\
\hline & HS-34 & HS-64 & HS-12 & HS-58 & HS-96 \\
\hline & HS-38 & HS-74 & HS-13 & HS-70 & \\
\hline & HS-40 & & HS-19 & HS-71 & \\
\hline \multirow{8}{*}{$\underset{\mathbf{0}}{\mathbf{R C A}_{\mathrm{AEC}} \leq}$} & HS-16 & & HS-17 & HS-35 & HS-73 \\
\hline & HS-44 & & HS-23 & HS-39 & HS-76 \\
\hline & HS-61 & & HS-22 & HS-42 & HS-82 \\
\hline & HS-94 & & HS-25 & HS-49 & HS-84 \\
\hline & & & HS-28 & HS-56 & HS-85 \\
\hline & & & HS-29 & HS-63 & HS-88 \\
\hline & & & HS-32 & HS-68 & HS-90 \\
\hline & & & HS-33 & HS-72 & HS-95 \\
\hline
\end{tabular}

Source: Secondary data from UN Comtrade, processed.

Table 4. reveals that in period 2009-2013 there are 9 (18\%) Indonesian commodities which have RCA index, $\mathrm{RCA}_{\mathrm{AEC}}$ and RCAwORLD, greater than 1. It means that those commodities have competitiveness not only in the AEC market but also in the global market. Further, in period 2009-2013 there are 13 (26\%) Indonesian commodities which have competitiveness in AEC market but not in the global market. Next, in period 2009-2013 there are four (8\%) of Indonesian commodities which have competitiveness in the global market but not in AEC market. Unfortunately, in period 2009-2013 there are 24 (48\%) Indonesian commodities which have no competitiveness either in AEC or global market. Overall, in period 2009-2013 there are 22 (44\%) Indonesian commodities which have competitiveness in AEC market. It means that after the global financial crisis Indonesia tends to be ready to enter the AEC. However, this achievement is lower compared with period 2003-2008. It seems that the global financial crisis has significant impact on Indonesian commodities competitiveness.

From calculations of RCA indices in period 2003-2008 and 2009-2013, it is obvious that before and after the global financial crisis there are $19(38 \%)$ of 
Indonesian commodities which have competitiveness in AEC market. It seems that those commodities have a stable demand and productivity in those periods. Those commodities are fish, crustaceans, molluscs, aquatic invertebrates nes (HS03), dairy products, eggs, honey, edible animal product nes (HS-04), edible fruit, nuts, peel of citrus fruit, melons (HS-08), oil seeds, oleagic fruits, grain, seed, fruit, etc, nes (HS-12), lac, gums, resins, vegetable saps and extracts nes (HS-13), cereal, flour, starch, milk preparations and products (HS-19), mineral fuels, oils, distillation products, etc (HS-27), pharmaceutical products (HS-30), soaps, lubricants, waxes, candles, modeling pastes (HS-34), rubber and articles thereof (HS-40) (as predicted by Lembang and Pratomo (2013)), paper and paperboard, articles of pulp, paper and board (HS-48), articles of apparel, accessories, not knit or crochet (HS-62), footwear, gaiters and the like, parts thereof (HS-64), glass and glassware (HS-70), pearls, precious stones, metals, coins, etc (HS-71), copper and articles thereof (HS-74), miscellaneous articles of base metal (HS-83), vehicles other than railway, tramway (HS-87), and miscellaneous manufactured articles (HS-96).

To make a comparison with other ASEAN-5 countries, this paper uses the same approach to find the main commodities (commodities which have competitiveness in AEC and global market) of the Philippines, Malaysia, Thailand, and Singapore. However, the data of export for the Philippines and Malaysia are incomplete. Therefore, for the four ASEAN-5 this study calculates RCA index for only 47 commodities. The following figure summarizes the results (in percentage to be suitable for comparison) for the period 2003-2008.

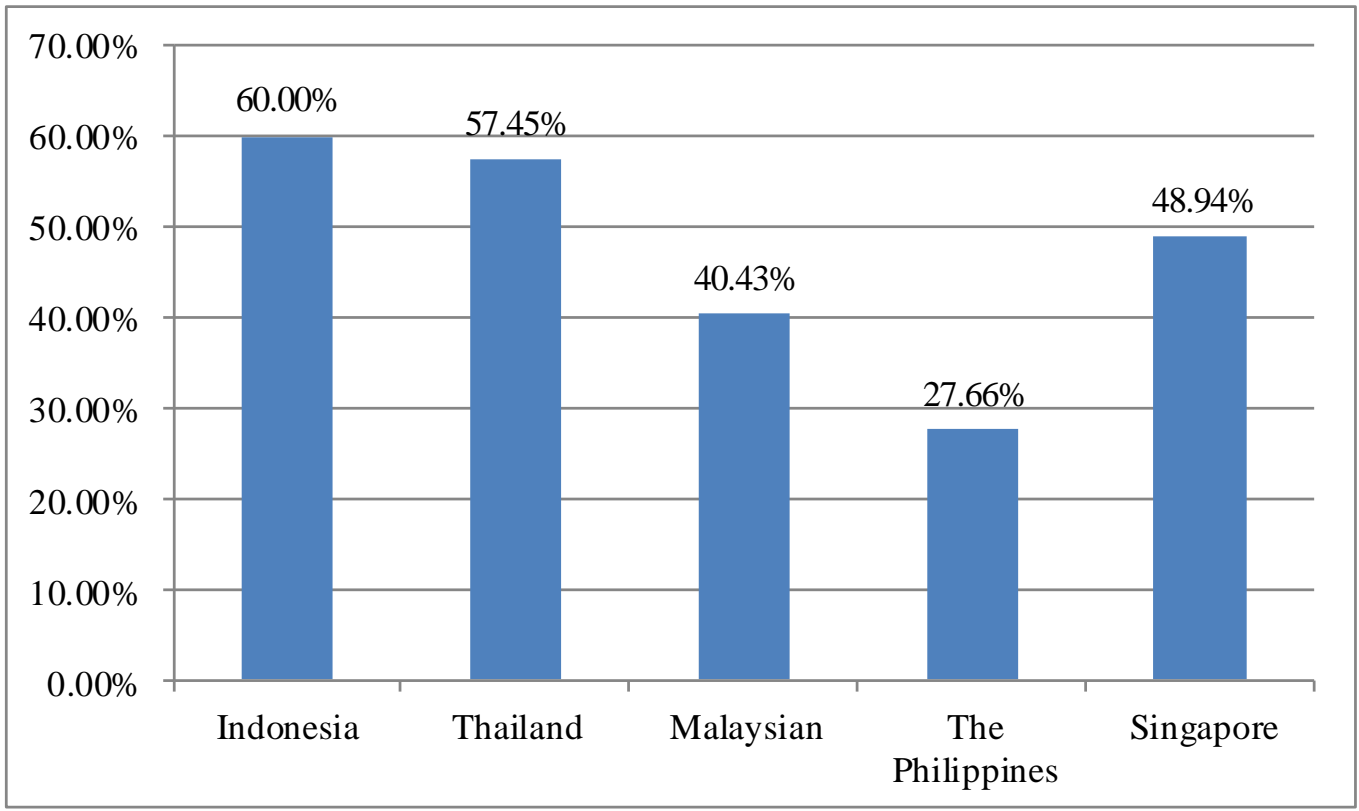

Figure 1. Comparison of ASEAN-5 Main Commodities, Period 2003-2008 Source: Secondary data from UNComtrade, processed.

In period 2003-2008, Indonesia leads. The country has more main commodities compared to other ASEAN-5 countries. However, that condition is different in period 2009-2013. Indonesia's position declines to number three following Malaysia and Thailand. See Figure 2. What is more, from Figure 1. and 
Figure 2., it is clearly seen that Malaysia is the only country in ASEAN-5 which is not affected by the global financial crisis. It seems that the country can generate economic advantages from the crisis. Therefore, Malaysia can improve the number of main commodities (from $40.43 \%$ to $55.32 \%$ ) after the crisis. Other ASEAN-5 countries are affected by the global financial crisis because their main commodities decline after the crisis.

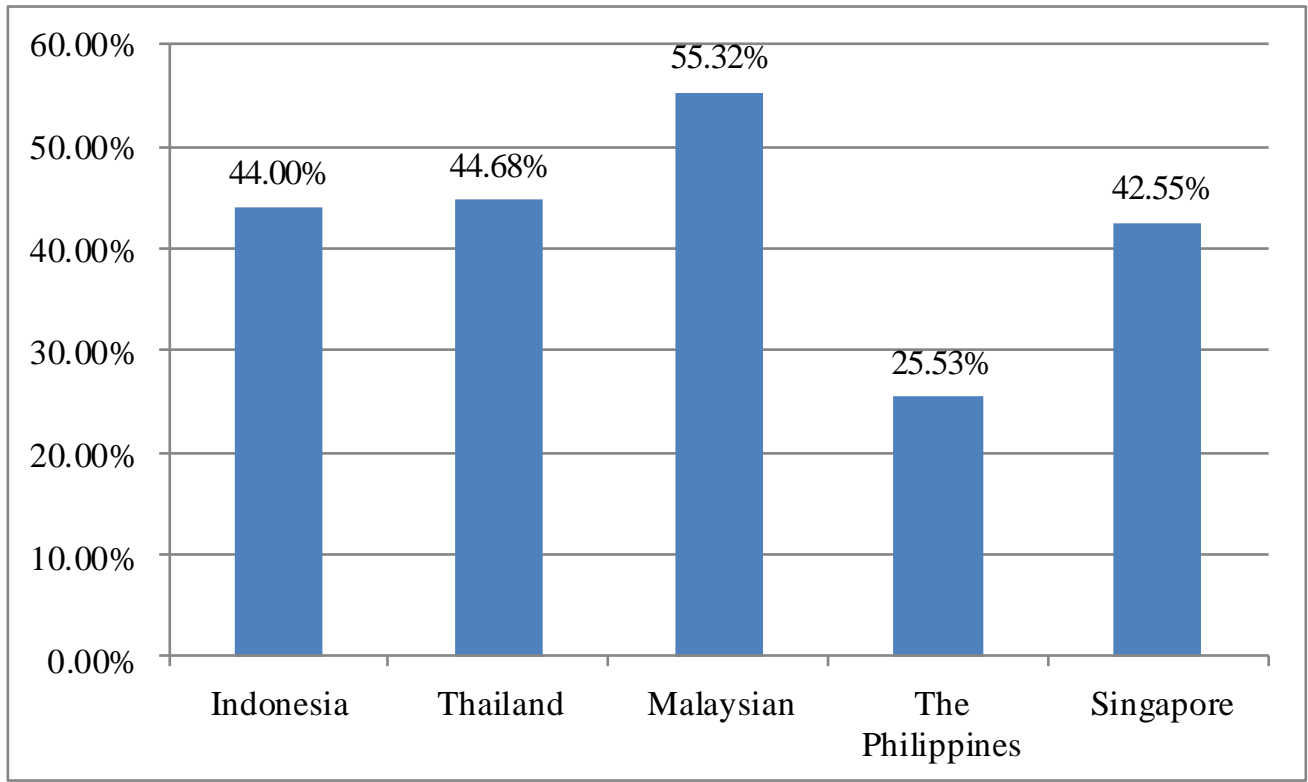

Figure 2. Comparison of ASEAN-5 Main Commodities, Period 2009-2013

Source: Secondary data from UNComtrade, processed.

\section{The Dynamics of Indonesian Commodities}

Calculations of DRCA $\mathrm{AEC}_{\mathrm{A}}$ and DRCAworLD indices are divided into two periods, i.e. before and after the global financial crisis in 2008. After calculating DRCA $_{\mathrm{AEC}}$ and DRCA ${ }_{\text {WORLD }}$ indices, the commodities are grouped into a matrix form. Here are the results:

Table 5. DRCA Matrix, Period 2003-2008

\begin{tabular}{lllllll}
\hline & \multicolumn{3}{c}{ DRCA } & & \multicolumn{2}{c}{ DRCA } \\
\hline DRCAORLD $_{\text {AEC }}>\mathbf{0}$ 0 & HS-08 & HS-21 & HS-56 & HS-58 & HS-90 & \\
\cline { 2 - 7 } & HS-12 & HS-38 & HS-72 & HS-71 & HS-95 & \\
\cline { 2 - 7 } & HS-16 & HS-40 & HS-88 & HS-82 & HS-96 & \\
\hline DRCA AEC $\leq$ 0 $^{\text {HS-04 }}$ & HS-32 & HS-73 & HS-03 & HS-44 & HS-85 \\
\cline { 2 - 7 } & HS-13 & HS-33 & HS-76 & HS-25 & HS-62 & HS-94 \\
\cline { 2 - 7 } & HS-17 & HS-34 & HS-83 & HS-27 & HS-63 & \\
\cline { 2 - 7 } & HS-19 & HS-35 & HS-84 & HS-29 & HS-64 & \\
& HS-22 & HS-48 & HS-87 & HS-30 & HS-68 & \\
\cline { 2 - 7 } & HS-23 & HS-49 & & HS-39 & HS-70 & \\
\cline { 2 - 6 } & HS-28 & HS-61 & & HS-42 & HS-74 &
\end{tabular}

Source: Secondary data from UN Comtrade, processed. 
Table 5. reveals that in period 2003-2008 there are 9 (18\%) Indonesian commodities which have DRCA index, DRCA AEC and DRCAworLD, greater than 1. It means that those commodities have growing competitiveness not only in the AEC market but also in the global market. Further, in period 2003-2008 there are $6(12 \%)$ Indonesian commodities which have growing competitiveness in AEC market but not in the global market. Next, in period 2003-2008 there is 19 (38\%) Indonesian commodities which have growing competitiveness in the global market but not in AEC market. Unfortunately, in period 2003-2008 there are 16 (32\%) Indonesian commodities which have no growing competitiveness either in AEC or global market. Overall, in period 2003-2008 there are 15 (30\%) Indonesian commodities which have growing competitiveness in AEC market.

Table 6. DRCA Matrix, Period 2009-2013

\begin{tabular}{|c|c|c|c|c|}
\hline \multirow{3}{*}{$\begin{array}{c}\text { DRCA AEC } \\
>0\end{array}$} & \multicolumn{3}{|c|}{ DRCA worLd $>0$} & \multirow{2}{*}{$\begin{array}{c}\text { DRCAwORLD } \leq \text { 0 } \\
\text { HS-17 }\end{array}$} \\
\hline & HS-03 & HS-33 & HS-61 & \\
\hline & HS-16 & HS-34 & HS-64 & HS-25 \\
\hline & HS-19 & HS-38 & HS-73 & HS-70 \\
\hline & HS-21 & HS-42 & HS-82 & \\
\hline & HS-22 & HS-44 & HS-85 & \\
\hline & HS-30 & HS-49 & HS-87 & \\
\hline & HS-32 & HS-58 & HS-95 & \\
\hline \multirow{8}{*}{$\begin{array}{c}\text { DRCAAEC } \\
\quad \leq 0\end{array}$} & HS-08 & HS-39 & HS-76 & HS-04 \\
\hline & HS-12 & HS-40 & HS-83 & HS-72 \\
\hline & HS-13 & HS-48 & HS-84 & HS-74 \\
\hline & HS-23 & HS-56 & HS-90 & HS-88 \\
\hline & HS-27 & HS-62 & HS-94 & \\
\hline & HS-28 & HS-63 & HS-96 & \\
\hline & HS-29 & HS-68 & & \\
\hline & HS-35 & HS-71 & & \\
\hline
\end{tabular}

Source: Secondary data from UN Comtrade, processed.

Table 6. reveals that in period 2009-2013 there are 21 (42\%) Indonesian commodities which have DRCA index, DRCA $\mathrm{AEC}_{\text {and }}$ DRCAwORLD, greater than 1. It means that those commodities have growing competitiveness not only in the AEC market but also in the global market. Compared to period 2003-2008, this is a significant increased. However, there is a huge influx of commodities in this group. 66 per cent of commodities are moving out the group, and 90 percent commodities are moving in the group. Further, in period 2009-2013 there are 3 (6\%) Indonesian commodities which have growing competitiveness in AEC market but not in the global market. Next, in period 2009-2013 there are 22 (44\%) of Indonesian commodities which have growing competitiveness in the global market but not in AEC market. Unfortunately, in period 2009-2013 there are 4 (8\%) Indonesian commodities which have no growing competitiveness either in AEC or global market. Overall, in period 2009-2013 there are 24 (48\%) Indonesian commodities which have growing competitiveness in AEC market. This achievement is higher compared with period 2003-2008. It means that after 
the global financial crisis Indonesia tends to be ready to enter the AEC. From the dynamics analysis, it seems that the global financial crisis may have significant impact on improving Indonesian commodities competitiveness.

From calculations of DRCA indices in period 2003-2008 and 2009-2013, it is obvious that before and after the global financial crisis there are $6(12 \%)$ of Indonesian commodities which have growing competitiveness in AEC market. It seems that those commodities have a growing demand and growing productivity in those periods. Those commodities are meat, fish and seafood food preparations nes (HS-16), miscellaneous edible preparations (HS-21), miscellaneous chemical products (HS-38), special woven or tufted fabric, lace, tapestry etc (HS-58), tools, implements, cutlery, etc of base metal (HS-82), and toys, games, sports requisites (HS-95).

To make a comparison with other ASEAN-5 countries, this paper uses the same approach to find the growing competitiveness of main commodities of the Philippines, Malaysia, Thailand, and Singapore. However, the data of export for the Philippines and Malaysia are incomplete. Therefore, for the four ASEAN-5 this study calculates DRCA index for only 47 commodities. The following figure summarizes the results (in percentage to be suitable for comparison) for the period 2009-2013.

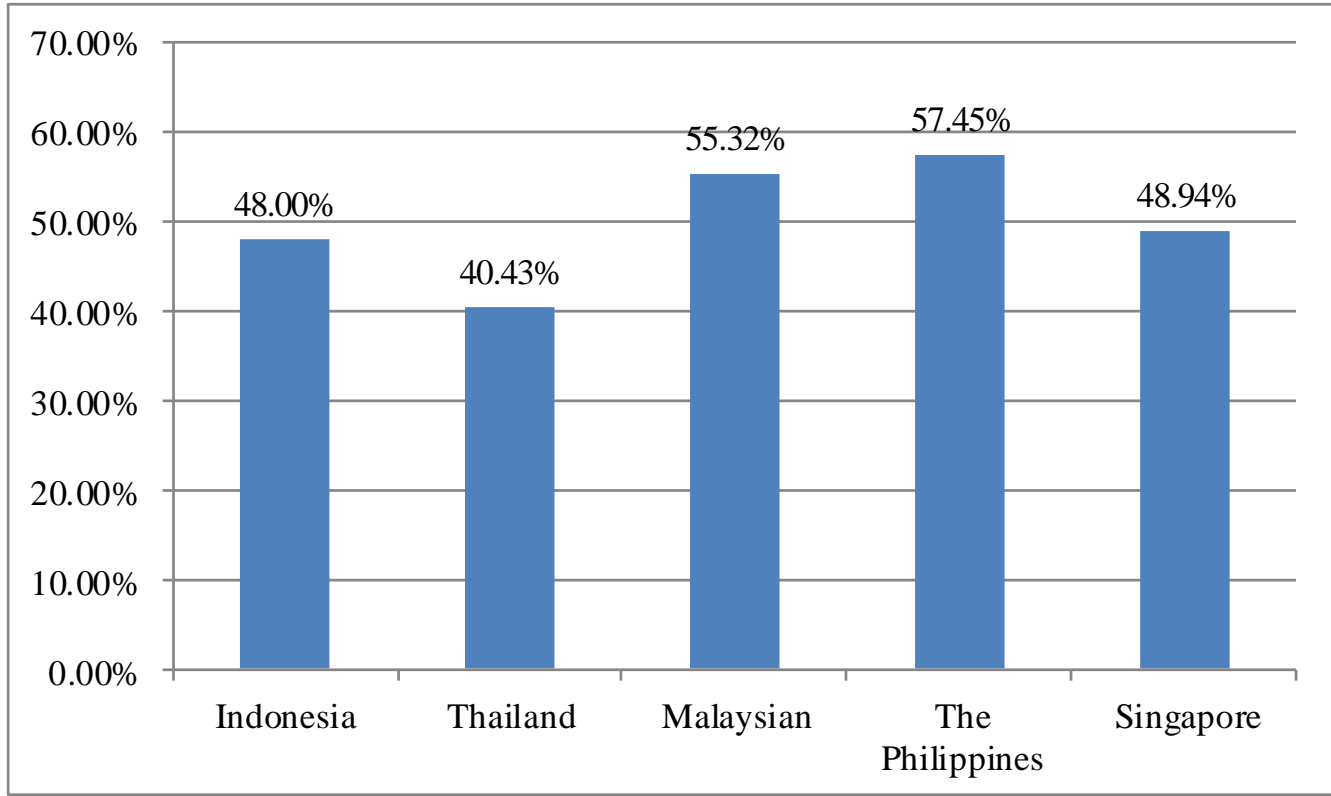

Figure 3. Comparison of ASEAN-5 Growing Main Commodities, Period 2009-2013 Source: Secondary data from UNComtrade, processed.

Figure 3. shows that in period 2009-2013 the Philippines leads. The country has more growing main commodities compared to other ASEAN-5 countries. Indonesia is in fourth. However, all the ASEAN-5 countries seems to be in the same level of growing competitiveness commodities before entering AEC. 


\section{Comparison with the Previous Studies}

One of the findings in this research, in period 2009-2013, is in line with the finding of Ragimun (2012a) who claimed that Indonesia is suitable as an exporter of footwear (HS-64). Footwear, this research contends, has competitiveness in AEC and global market. Furthermore, footwear has growing competitiveness in AEC and global market. Therefore, this article predicts that footwear, for Indonesia, could be leading commodities in AEC.

Next, when comparing the results in Table 3. To Table 4., and Table 5. To Table 6., there is a surprising result. Iron and steel (HS-72), which is originally located in the first row in period 2003-2008, it moves to area IV in period 20092013. These movements occur both in RCA and DRCA matrix. However, Maulidy and Widyasanti (2011) argues that iron and steel is a rising star (DRCA is at area I) commodity, which means that iron and steel has a competitive advantage to compete in the global market. These contradictive results become attractive to discuss. After reviewing the data, although the data obtained are the same, i.e. sourced from UN Comtrade, however, the period of studies are different. Iron and steel indeed increase over the study of Maulidy and Widyasanti (2011). This happens until 2010. From 2003, the trend of iron and steel exports continues to rise, reaching a peak in 2008, not only for Indonesian exports but also for ASEAN and the world. In 2009, exports of iron and steel decline quite sharply and increase again in 2010 and 2011. This increase makes iron and steel to be a rising star (Maulidy \& Widyasanti, 2011). However, in 2012, iron and steel exports decline up to 2013. This is why the results of this study show that iron and steel are not included in the Indonesia's main commodities.

\section{Indonesia's Readiness to face AEC}

The condition of Indonesian commodities in the period 2003-2008 seems not to be convincing. Uncertainty is increasingly seen by the position of Indonesia in the Global Competitiveness Index (GCI) Report in 2008-2009 (Schwab \& Porter, 2008), which puts Indonesia in rank 55. The position is very far ahead of nearest rivals, i.e. Brunei Darussalam which is ranked at number 39, and Thailand which is ranked at number 34. In period 2003-2008, Malaysia is ranked at number 21, while Singapore is in rank 5. The Philippines, in period 2003-2008, is still below Indonesia which is ranked at 71 .

What is important, Indonesia's rank has continuously increased in period 2009-2013 and 2013-2014. In the Global Competitiveness Index (GCI) reports for 2012-2013 (Schwab, 2012), Indonesia is ranked at number 50. Thailand is the closest, which ranked at number 38. Brunei Darussalam, further, strengthens its position in the top 28, with Malaysia is in rank 25. Singapore is at number 2. The Philippines is still below Indonesia, which is at rank 65. In period 2013-2014 (Schwab, 2013), Indonesia jumps to rank 38 where Thailand is at number 37. In this period, Brunei Darussalam is at rank 26, and Malaysia is at number 24. Singapore, however, remains in the second position, the Philippines strengthens its position to be at number 59 .

Based on GCI reports and RCA and DRCA matrix, in sum, this article believes that Indonesia is ready to compete in AEC. However, this readiness, still, needs to be evaluated by looking at Indonesian government export's strategy 
direction. Table 7. shows the comparison between Indonesian government export's strategy direction and results from RCA and DRCA matrix.

Table 7. Comparison of Study Results with Government Policy Direction

\begin{tabular}{|c|c|c|c|}
\hline Sector & $\begin{array}{l}\text { HS } \\
\text { Code }\end{array}$ & Commodity name & Superior \\
\hline Fishery*** & 03 & $\begin{array}{l}\text { Fish, crustaceans, molluscs, aquatic } \\
\text { invertebrates nes }\end{array}$ & Yes \\
\hline \multirow{3}{*}{$\begin{array}{l}\text { Vegetable } \\
\text { products**** }\end{array}$} & 08 & Edible fruit, nuts, peel of citrus fruit, melons & Yes \\
\hline & 12 & $\begin{array}{l}\text { Oil seed, oleagic fruits, grain, seed, fruit, etc, } \\
\text { nes }\end{array}$ & Yes \\
\hline & 13 & $\begin{array}{l}\text { Lac, gums, resins, vegetable saps and extracts } \\
\text { nes }\end{array}$ & Yes \\
\hline Rubber*** & 40 & Rubber and articles thereof & Yes \\
\hline \multirow{3}{*}{$\begin{array}{l}\text { Wood and Wood } \\
\text { Products** }\end{array}$} & 44 & Wood and articles of wood, wood charcoal & No \\
\hline & 48 & $\begin{array}{l}\text { Paper \& paperboard, articles of pulp, paper } \\
\text { and board }\end{array}$ & Yes \\
\hline & 49 & Printed books, newspapers, pictures etc & No \\
\hline \multirow[t]{5}{*}{ Textiles** } & 56 & $\begin{array}{l}\text { Wadding, felt, nonwovens, yarns, twine, } \\
\text { cordage, etc }\end{array}$ & No \\
\hline & 58 & $\begin{array}{l}\text { Special woven or tufted fabric, lace, tapestry } \\
\text { etc }\end{array}$ & Yes \\
\hline & 61 & Articles of apparel, accessories, knit or crochet & No \\
\hline & 62 & $\begin{array}{l}\text { Articles of apparel, accessories, not knit or } \\
\text { crochet }\end{array}$ & Yes \\
\hline & 63 & $\begin{array}{l}\text { Other made textile articles, sets, worn clothing } \\
\text { etc }\end{array}$ & No \\
\hline Machine* & 84 & Nuclear reactors, boilers, machinery, etc & No \\
\hline Electronic devices** & 85 & Electrical, electronic equipment & No \\
\hline \multirow[t]{2}{*}{ Transportation** } & 87 & Vehicles other than railway, tramway & Yes \\
\hline & 88 & Aircraft, spacecraft, and parts thereof & No \\
\hline
\end{tabular}

Source: Secondary data from UN Comtrade, processed.

*** denotes main commodities and should be increasing

** denotes not main commodities, but potential

* denotes not potential

From Table 7., it is obvious that Indonesian government policy direction is good enough. It is clearly seen that the Government of Indonesia is giving priority to developing several main commodities, although there are several commodities which are less potential, but those have been prioritized.

\section{CONCLUSION}

This study claims that Indonesia is ready to face the AEC. There are two reasons behind the claim. First, the country has, at least 40 percent, commodities which have comparative advantages in ASEAN region. With that percentage, Indonesia is ranked at the top four of the ASEAN nations. Second, GCI confirms that Indonesia's competitiveness level increased significantly, where it jumped 12 ranks (ranked at 38) from 2013 to 2014 compared with the previous period. The progress is more rapid when compared with other ASEAN-6 countries. 
From this research, there are several Indonesian main commodities indicated. Those are fish, crustaceans, molluscs, aquatic invertebrates nes (HS03), edible fruit, nuts, peel of citrus fruit, melons (HS-08), oil seed, oleagic fruits, grain, seed, fruit, etc, nes (HS-12), lac, gums, resins, vegetable saps and extracts nes (HS-13), rubber and articles thereof (HS-40), paper \& paperboard, articles of pulp, paper and board (HS-48), special woven or tufted fabric, lace, tapestry etc (HS-58), articles apparel, accessories, not knit or crochet (HS-62), and vehicles other than railway, tramway (HS-87). Those commodities are in line with Indonesian government export's strategy direction which mainly focuses on several sectors, including fishery, vegetable products, rubber, wood and wood products, textiles, and transportation.

It is recognized that the methods used in this study cannot be used to predict, in the future, whether a commodity remains superior or not. For further research, there is a need to employ stationary test so that the competitiveness level of a product can be determined whether it will be still superior in the future or not.

\section{REFERENCES}

Aldrich, J. (2004). The Discovery of Comparative Advantage. Journal of History of Economic Thought, 26(3), 379-399.

Balassa, B. (1965). Trade Liberalization and "Revealed" Comparative Advantage. The Manchester School of Economic and Social Studies, 33(2), 99-123.

Balassa, B., \& Noland, M. (1989). "Revealed" Comparative Advantage in Japan and the United States. Journal of International Economic: Integration, 4 (2), 8-22.

Bouare, O. (2009). An Evaluation of David Ricardo's Theory of Comparative Costs: Direct and Indirect Critiques. Journal of Economic Development, 34(1), 99-125.

Bustami, G. (2008). Мепијu ASEAN Economic Community 2015. Jakarta: Departemen Perdagangan Republik Indonesia.

Edwards, L. \& Schoer, V. (2001). The Structure and Competitiveness of South African Trade. TIPS Annual Forum, pp. 10-12.

Firdaus, M. (2009). How Severely Did The Global Economic Crisis Affect Indonesian Agribusiness Exports? AFBE 2010 Conference Papers, Vol. 2008. No. 14.97.

Gayati, M.D. (2014). Indonesia Miliki 12 Sektor Prioritas Hadapi MEA. Retrieved from Antaranews.com.

Hermana, B. (2004). Mendorong Daya Saing di Era Informasi dan Globalisasi: Pemanfaatan Modal Intelektual dan Teknologi Informasi sebagai Basis Inovasi di Perusahaan. Jakarta: Universitas Gunadarma.

Ishchukova, N., \& Smutka, L. (2013). Revealed Comparative Advantage of Russian Agricultural Exports. Acta Universitatis Agriculturae et Silviculturae Mendelianae Brunensis.

Kalaba, Y. (2012). Analisis Daya Saing Kakao Indonesia. Disertasi tidak diterbitkan. Yogyakarta: Universitas Gadjah Mada.

Karambakuwa, R., \& Mzumara, M. (2013). The Revealed Comparative Advantage of Swaziland. Greener Journal of Economics and Accountancy, 2(2), 68-73. 
Lembang, M.B., \& Pratomo, Y. (2013). Ekspor Karet Indonesia ke-15 Negara Tujuan Utama Setelah Pemberlakuan Kebijakan ACFTA. Trikonomika, 12(1), 20-31.

Maulidy, M.R., \& Widyasanti, A.A. (2011). Daya Saing Produk Ekspor Manufaktur Indonesia dengan Metode RCA Dinamis. Jurnal Perencanaan Pembangunan, 17(1), 12-15.

Muslim, C. (2006). Analisis Daya Saing Produk Ekspor Agroindustri Komoditas Berbasis Kelapa di Indonesia. Jakarta: Badan Penelitian dan Pengembangan Pertanian, Departemen Pertanian.

Ragimun. (2012a). Analisis Perdagangan Produk Alas Kaki Indonesia - China. Kajian Ekonomi Keuangan, 16(2), 1-21.

Ragimun. (2012b). Analisis Daya Saing Komoditas Kakao Indonesia. Jurnal Pembangunan Manusia, 6(2), 1-24.

Rifin, A. (2013). Competitiveness of Indonesia's Cocoa Beans Export in the World Market. International Journal of Trade, Economics, and Finance, 4(5), 279-281.

Schwab, K., \& Porter, M.E (Eds). (2008). The Global Competitiveness Report 2008-2009. Geneva: World Economic Forum.

Schwab, K. (Eds). (2012). The Global Competitiveness Report 2012-2013. Geneva: World Economic Forum.

Schwab, K. (Eds). (2013). The Global Competitiveness Report 2013-2014. Geneva: World Economic Forum.

Serin, V., \& Civan, A. (2008). Revealed Comparative Advantage and Competitiveness: A Case Study for Turkey toward the EU. Journal of Economic and Social Research, 10(2), 25-41.

Sholeh. (2013). Persiapan Indonesia Dalam Menghadapi AEC (ASEAN Economic Community) 2015. eJournal Ilmu Hubungan Internasional, 1(2), 509-522.

Suntharalingam, C., Ahmad, TMAT., Ali, AK., Rusli, R., \& Halim, NA. (2011). Competitiveness of Malaysia's Fruits in the Global Agricultural and Selected Export Markets: Analyses of Revealed Comparative Advantage (RCA) and Comparative Export Performance (CEP). Economic and Technology Management Review, 6, 1-17.

Valentine, N., \& Krasnik, G. (2000). SADC Trade with the Rest of the World: Winning Export Sectors and Revealed Comparative Advantage Ratios. South African Journal of Economics, 68(2) 114-124.

Widgrén, M. (2005). Revealed Comparative Advantage in the Internal Market. ETLA Discussion Papers, The Research Institute of the Finish Economy. 